\title{
JUAN SALAMANCA
}

UNIVERSITY OF ILLINOIS URBANA-CHAMPAIGN ESCUELA DE ARTE Y DISEÑO

CHAMPAIGN, EE.UU.

jsal@illinois.edu

\section{DISEÑO DE ARTEFACTOS PERFORMATIVOS PARA MEDIACIONES SIMÉTRICAS}

DISEÑA 13 I AGOSTO 2018 ISSN: $0718-8447$ (IMPRESO); 2452-4298 (ELECTRÓNICO)

ARTÍCULO DE INVESTIGACIÓN ORIGINAL

RECEPCIÓN: 7 DE MAYO 2018 I ACEPTACIÓN: 7 DE JULIO 2018

CÓMO CITAR ESTE ARTÍCULO:

SALAMANCA, J. (2018). Diseño de artefactos performativos para mediaciones simétricas. Diseña, (13), 174-207.

Doi: 10.7764/disena.13.174-207

TRADUCCIÓN: JOSÉ MIGUEL NEIRA

DISEÑA 13 I AUGUST 2018 I ISSN: $0718-8447$ (PRINT); 2452-4298 (ELECTRONIC)

ORIGINAL RESEARCH ARTICLE

RECEPTION: MAY 7, 2018 I ACCEPTANCE: JULY 7, 2018

HOW TO CITE THIS ARTICLE:

Salamanca, J. (2018). Designing Performative Artifacts for Symmetrical Mediation. Diseña, (13), 174-207.

Doi: 10.7764/disena.13.174-207

J UA N SALAMA NCA

UNIVERSITY OF ILLINOIS URBANA-CHAMPAIGN SCHOOL OF ART AND DESIGN

CHAMPAIGN, USA

jsal@illinois.edu 


\section{Juan Salamanca}

Licenciado en Diseño Industrial, Pontificia Universidad Javeriana. Magíster en Dirección de Diseño, Domus Academy. Doctor en Diseño, Illinois Institute of Technology. Profesor Asistente en el Departamento de Diseño Gráfico de la Escuela de Arte y Diseño de la University of Illinois Urbana-Champaign. Se dedica a la investigación en diseño sobre interacciones sociales en ambientes aumentados, ahondando específicamente en cómo diseñar artefactos inteligentes y socialmente aptos. Algunas de sus últimas publicaciones son: "Smart Artifacts Mediating Social Viscosity" (en Digitalsts: A Handbook and Fieldguide, Princeton University Press, 2019) y "Demo: A Prototype for a Platoon-based Cyclist Cooperative System" (con S. Céspedes, D. Vinasco y A. Yáñez, I ee e Vehicular Networking Conference, 2017).

\section{Resumen}

En este artículo se introducen algunas propuestas de diseño que pretenden dar luces al diseño de mediadores artificiales adaptables a interacciones sociales. El argumento que se presenta en este estudio está enmarcado en las definiciones de cooperación y colaboración; dos formas de interacción social que se apoyan en mecanismos en los cuales los participantes reconocen mutuamente sus intenciones y sus agencias, e interactúan teniendo en cuenta diferentes balances de privilegios y obligaciones. A través del análisis de las interacciones intervenidas con mediadores adaptables, este artículo da evidencia, a partir de cuatro propuestas de diseño, que artefactos adaptables diseñados con un lenguaje subjuntivo ofrecen mejores resultados cuando fomentan interacciones cooperativas; mientras que los diseñados con un lenguaje prescriptivo son más efectivos mediando interacciones colaborativas. Además, este estudio propone que se deberían preferir los lenguajes simbólicos prescriptivos cuando la mediación aborda una distribución de recursos desbalanceada.

Palabras clave: Interacciones sociales, diseño para la mediación, cooperación, colaboración, viscosidad social

\footnotetext{
Juan Salamanca

BA in Industrial Design, Pontificia Universidad Javeriana. MA in Design Direction, Domus Academy. Ph.D. in Design, Illinois Institute of Technology. He is Assistant Professor in the Graphic Design Department at the University of Illinois UrbanaChampaign's School of Art and Design. He conducts design research on social interaction in augmented environments, specifically exploring how to design socially apt smart artifacts. Some of his latest publications are: 'Smart Artifacts Mediating Social Viscosity' (in Digitalsts: A Handbook and Fieldguide, Princeton University Press, 2019) and 'Demo: A Prototype for a Platoonbased Cyclist Cooperative System' (with S. Céspedes, D. Vinasco, and A. Yáñez, I EE E Vehicular Networking Conference, 2017).
}

\begin{abstract}
This paper introduces some design propositions that aim at enlightening the design of adaptive artificial mediators of social interactions. The argument presented herein is framed in the context of working definitions of cooperation and collaboration; two forms of social interaction based on mechanisms in which parties mutually recognize their intentionality, recognize each other's agency, and operate under different balances of privileges and obligations. Through the analysis of interactions with adaptive mediators, the paper concludes in four design propositions that subjunctive design language could yield better outcomes when adaptive artifacts foster cooperative interactions, whereas prescriptive ones work better in collaborative interactions. Moreover, it proposes that prescriptive symbolic languages should be preferred when the mediation is about an imbalanced distribution of resources.

Keywords: Social interaction, Design for mediation, Cooperation, Collaboration, Social viscosity
\end{abstract}




\section{INTRODUCCIÓN}

La mediación de interacciones supone la existencia de al menos dos partes asistidas por una tercera, la cual las ayuda a orientar o resolver su interacción. Las características de la mediación están determinadas por el tipo de interacción y por la concepción de las partes acerca de los resultados aceptables de dicha interacción. Por ejemplo, cuando un grupo de conductores viaja por vías congestionadas necesita un tipo de mediación diferente de la que necesitan cuando tratan de compartir sus vehículos. En ambos casos, la consideración de cada conductor por el otro, el alineamiento respecto de sus metas y la compatibilidad de sus acciones son aspectos que determinan si un mediador debe promover una interacción cooperativa o colaborativa. El diseño para la mediación abarca estos aspectos y concibe el diseño de mediadores justos y sin sesgo que faciliten la acción colectiva al desplegar cursos de acción balanceados respecto a las partes de la interacción. Nuestro argumento se enmarca en el contexto de la acción simultánea, en la cual los actores reconocen mutuamente su agencia y se espera un balance entre sus obligaciones y sus privilegios. Esta forma de interacción social, más allá de la preocupación de una parte por la otra, suele denominarse en la literatura como "cooperación". Para mencionar dos trabajos fundamentales en el área, Axelrod (1984) señala que la cooperación emerge de la reciprocidad entre individuos que persiguen sus propios intereses. Tomasello (2010) toma una postura distinta. Para él, la cooperación se basa en mecanismos de intencionalidad comparti-

\section{INTRODUCTION}

The mediation of interactions assumes the existence of at least two parties assisted by a third one who helps them to resolve or drive their interaction. The characteristics of the mediation are determined by the kind of interaction and parties' conception of acceptable interaction outcomes. For instance, car drivers using overcrowded roads need a different mediation than the same drivers pooling their vehicles. In either case the drivers' consideration for each other, the alignment of their goals, and the compatibility of their doings, are aspects that determine whether a mediator calls for cooperative or collaborative interactions. Design for mediation embraces these aspects and envisions the design of fair and unbiased mediators that facilitate collective action by conveying balanced courses of action to the parties in interaction.

I frame my argument in the context of concurrent action in which individuals' agency is mutually recognized, and the balance of privileges and obligations is expected. Such form of social interaction, regardless of the parties' care for each other, is often named in the literature as 'cooperation'. To mention two seminal works in the field, Axelrod (1984) argues that cooperation emerges from reciprocity between individuals pursuing their own self-interests. Tomasello (2010) takes a different stance. For him, co- 
da, adquiridos cuando los niños intentan alcanzar metas compartidas con otros. Nosotros ofrecemos un marco para el análisis de estos tipos de interacciones que diferencia la cooperación de la colaboración. En este artículo, el significado del sustantivo "cooperación" está alineado con la definición que da Axelrod, mientras que el significado de "colaboración" es afín a la definición de Tomasello. Según lo planteamos en las siguientes secciones, esto no solo es útil para articular nuestra argumentación, sino que sirve como una herramienta conceptual para el diseño de mediadores.

Las partes involucradas en una interacción, sea o no conflictiva, se pueden beneficiar de la participación de mediadores diseñados: en el caso de partes en divergencia, ayudándolas a alcanzar un acuerdo cooperativo y satisfactorio; en el caso de partes consecuentes, articulando un diálogo colaborativo entre ellas. No obstante, muy pocas veces es posible observar la cooperación y la colaboración en su expresión pura. Lo que se observa en las interacciones sociales cotidianas es más una mezcla de modelos relacionales (Fiske, 2004) que caracterizan las acciones inarmónicas de individuos que buscan su beneficio, ya sea como miembros de un grupo social o por sí mismos.

Las ideas expuestas en este artículo son visiones optimistas sobre la forma en que el diseño de artefactos podría ayudar a diferentes actores a alcanzar la utopía de interactuar balanceadamente. Generalmente, la participación de un mediador se inicia en cuanto surge una situación problemática. Nosotros visualizamos que los mediadores diseñados

operation is based on mechanisms of shared intentionality acquired when children try to achieve shared goals with others. I offer a framework for the analysis of these kinds of interaction that differentiate cooperation from collaboration. In this essay, the meaning of the noun 'cooperation' is aligned with Axelrod's definition, whereas the meaning of 'collaboration' is akin to Tomasello's definition. As I discuss in the following sections, this grammatical distinction is not only useful to articulate my argument but serves as a conceptual tool for the design of mediators.

Parties in either conflictive and non-conflictive interaction could benefit from the participation of designed mediators. In the case of divergent parties, by helping them to reach a cooperative satisfying disentanglement, and in the case of consequent parties, by articulating a collaborative dialogue between them - but cooperation and collaboration are rarely observed in their pure form. What we observe in everyday social interactions is rather a mélange of relational models (Fiske, 2004) that characterize the unharmonious actions of individuals aiming at doing better, either as members of a collective or by themselves.

The ideas presented herein are optimistic visions about how artifact design could assist parties to achieve utopic balanced interactions. The participation of a mediator typically starts once a problematic situation 
podrían anticipar tales situaciones con el objetivo de advertir a las partes involucradas sobre potenciales oportunidades de anticiparse a una interacción cooperativa o colaborativa. Esto implica que los artefactos podrían participar activamente en las interacciones sociales no solo como vehículos de información, sino también como agentes con la capacidad de sugerir cursos de acción. Tales sugerencias son transmitidas a través de lenguajes de diseño subjuntivos o prescriptivos. Con respecto a esto, la definición de "intermediario" y "mediador" propuesta en el marco de la teoría del actor-red es compatible con el marco conceptual para el análisis de una sociabilidad híbrida distribuida entre personas y artefactos. Sin embargo, nuestra perspectiva de los artefactos con agencia no se limita a los objetos inanimados, sino que también abarca artefactos que reaccionan a condiciones contextuales para fomentar estados de la realidad previstos (D'Inverno \& Luck, 2001).

Para poder generar un argumento que guíe al lector hacia nuestras propuestas para el diseño de mediadores, empezamos por introducir algunas líneas de investigación sobre la agencia computacional en las interacciones sociales que contemplan la participación de androides en formas naturales de sociabilidad. Después de esto, presentamos una definición funcional de las interacciones cooperativas y colaborativas. Luego, discutimos un modelo relacional de interacción social basado en la percepción de equivalencia entre partes en interacción, cerrando con la discusión de un diseño crítico que ilustra las oportunidades y desafíos del diseño para la mediación.

comes to life. I envision that designed mediators can anticipate such situations with the purpose of forewarning parties of potential opportunities for cooperative or collaborative interactions. This entails that artifacts could actively participate in social interactions not only as vehicles of information, but as agents with the capacity of suggesting courses of action. Such suggestions are conveyed by using prescriptive or subjunctive design languages. In this vein, the definition of 'intermediary' and 'mediator' from Actor-Network Theory (Callon \& Law, 1995; Latour, 1999; Law, 1992) better suits the conceptual framework for the analysis of a hybrid sociality distributed between people and designed artifacts. But my vision of agential artifacts is not constrained to inanimate things - it extends to artifacts that react to contextual conditions to foster an expected state of affairs (D'Inverno \& Luck, 2001).

In order to build an argument that guides the reader to some propositions for the design of mediators, I start by introducing some strands of research regarding computational agency in social interaction that envision the participation of androids in natural forms of sociality. Next, I present a working definition of cooperative and collaborative interactions. Then, I discuss a relational model of social interaction based on the perception of equivalence between the interacting parties, and close with 
Entre las líneas de investigación sobre la agencia computacional en las interacciones sociales, este estudio se interesa por enfoques orientados a la interacción con máquinas computacionales. Bullington (2009) presenta un marco teórico y una revisión del estado del arte de muchos proyectos de investigación sobre el diseño de agentes interactivos, todos ellos enfocados en las interacciones humanas con androides. La pregunta subyacente de estos proyectos se puede describir parafraseando el test de Turing: ¿Cómo se puede diseñar un androide para hacer creer a un humano que está interactuando con otro humano, cuando en realidad lo está haciendo con una máquina? El marco teórico abordado por Bullington se apoya en la "actitud intencional" de Dennett (1987), quien sugiere que, si tratamos a alguien o algo como un agente racional, primero necesitamos pensar en qué creencias debería tener dicho agente en relación con su lugar y propósito en el mundo. Segundo, es necesario considerar qué deseos debería tener en consideración con su estado y lugar en el mundo. Por último, los diseñadores necesitan predecir cómo actuará el agente para poder alcanzar sus metas. Un observador puede predecir lo que haría el agente en una circunstancia particular al razonar desde su conjunto de creencias y deseos. Cuando se predice el comportamiento de un agente, operamos en tres niveles de abstracción: la actitud física, donde estamos preocupados por las reacciones físicas y químicas del agente; la actitud de diseño, donde abordamos su propósito, estructura y funcionalidad; y la actitud inten-

the discussion of a critical design case that illustrates the opportunities and challenges of designing for mediation.

\section{COMPUTATIONAL AGENCY IN SOCIAL INTERACTION}

Among the research strands of computational agency in social interaction, this research is particularly interested in approaches oriented towards the interaction with computational machines. Bullington (2009) presents a theoretical framework and a survey of several research projects on the design of interactive agents, all of them having a particular focus on human interaction with androids. The underlying question of these projects could be depicted by paraphrasing the Turing test: How can an android be designed to make a human believe he/she is interacting with another human when in reality he/she is interacting with a machine?

The theoretical framework discussed by Bullington is based on Dennett's 'intentional stance' (Dennett, 1987). Dennett argues that if we are to treat something or someone as a rational agent, it is necessary to think first on what beliefs that agent ought to have in relation to its place in the world and purpose. Second, it is necessary to consider what desires it ought to have in consideration to its here-and-now. Finally, designers need to predict how the agent will act in order to fulfill its goals. An observer can 
cional, en la que nos enfocamos en sus creencias, deseos e intenciones.

Bullington recoge dos aspectos importantes de la investigación sobre los androides basados en diferentes formas de lenguaje humano: agentes conversacionales y comunicación no verbal. El primero se enfoca en robots de chats capaces de mantener una conversación (Cassell \& Bickmore, 2003), mientras que el último está orientado a robots y caracteres interactivos que aprenden y se adaptan a gestos (Breazeal, 2002) y emociones humanas (Bickmore \& Picard, 2005; Picard, 1995). Nosotros visualizamos el diseño de mediadores computacionales como un esfuerzo de diseño de comunicación que opera en las tres actitudes que propone Dennett (1987). En la actitud física nos enfrentamos al diseño de un medio adaptable y a la reificación del mensaje a través de dicho medio; en la actitud de diseño, al tipo de interacción en la que se espera que el agente sea mediador; y en la actitud intencional abordamos los principios morales que rigen el estado de los sucesos que se esperan en los acuerdos en los que se ha intervenido. En referencia a la última actitud, siempre hay acuerdos de poder y autoridad que se han iniciado en las tecnologías que moran el mundo social (Winner, 1980), y los artefactos que desempeñan interacciones cooperativas y colaborativas no son la excepción.

\section{DEFINICIÓN DE LAS INTERACCIONES COOPERATIVAS Y COLABORATIVAS}

En la literatura se han propuesto muchas clasificaciones de las in-

predict what the agent would do under a given circumstance by reasoning from the set of its beliefs and desires. When predicting the behavior of an agent we operate at three levels of abstraction: at the physical stance, we are concerned with the agent's physical and chemical reactions; at the design stance, we deal with its purpose, structure, and functionality; and at the intentional stance, we deal with its beliefs, desires and intentions.

Bullington features two major aspects of the research on androids based on different forms of human language: conversational agents, and nonverbal communication. The former focuses on chat bots capable of maintaining a conversation (Cassell \& Bickmore 2003), whereas the latter is focused on robots and interactive characters learning and adapting from human gestures (Breazeal, 2002) and emotions (Bickmore \& Picard, 2005; Picard, 1995). I envision the design of computational mediators as a communication design endeavor that operates at Dennett's three stances (1987). At the physical stance, we deal with the design of an adaptive medium and the reification of the message through such a medium; at the design stance with the kind of interaction the agent is intended to mediate; and at the intentional stance with the moral principles governing the state of affairs expected in mediated agreements. In regard to the latter stance, there are always arrangements of power and authority instantiated in the 
teracciones sociales: competición, conflicto, reconciliación y asimilación (Park \& Burgess, 1966); subordinación, superordinación, intercambio, conflicto y sociabilidad (Simmel \& Levine, 1971); cooperación (Axelrod, 1984; Fehr \& Gächter, 2002); cooperación y coerción (Nicholson, 1934/2004).

Las personas tienden a entrar en conflicto cuando sus intereses convergen por recursos únicos, limitados o escasos. Cuando las personas coordinan sus acciones para acceder simétricamente a los recursos, superan los conflictos, resultando en actividades cooperativas o colaborativas. La coordinación en balances deseados ha sido ampliamente estudiada en la teoría de juegos al analizar variaciones de juegos que están compuestos esencialmente por jugadores, estrategias y recompensas (Axelrod, 1984; Von Neumann \& Morgenstern, 1953). Los investigadores suelen estar de acuerdo en que el mejor escenario para los jugadores que intentan maximizar sus ganancias está descrito en el equilibrio de juegos de Nash. Dicho equilibrio se puede alcanzar cuando los jugadores ofrecen sus mejores respuestas a las estrategias de otros jugadores; en otras palabras, cada jugador acepta un resultado individual subóptimo que, en cambio, optimiza el resultado promedio de todos los jugadores. Schmidt y Simone (1996) ofrecen un enfoque diferente pero complementario a la coordinación en su estudio sobre el trabajo cooperativo de los artefactos mediadores. Ellos plantean que los artefactos y protocolos facilitan la articulación del trabajo y alivian la necesidad de una negociación y de una deliberación ad hoc. Esto deja

technologies dwelling in the social world (Winner, 1980), and artifacts conveying collaborative and cooperative interactions are no exception.

\section{DEFINITION OF COOPERATIVE AND COLLABORATIVE INTERACTIONS}

Many classifications of social interaction have been proposed in the literature: competition, conflict, accommodation, and assimilation (Park \& Burgess, 1966); subordination, super-ordination, exchange, conflict and sociability (Simmel \& Levine, 1971); cooperation (Axelrod, 1984; Fehr \& Gächter, 2002); cooperation and coercion (Nicholson, 1934/2004).

People tend to fall into conflict when their interests converge on unique, limited or scarce resources. When people coordinate their actions to symmetrically access the resources, they sort out conflicts, ending up in either cooperative or collaborative activities. Coordination in desired balances has been extensively studied in game theory by analyzing variations of games that are essentially composed of players, strategies and payoffs (Axelrod, 1984; Von Neumann \& Morgenstern, 1953). Researchers generally agree that the best scenario for players who try to maximize their payoffs is described by the game's Nash equilibrium. Such equilibrium can be achieved when players play their best response to the strategies of other players. In other words, every player agrees to an individual sub-optimal outcome 
en evidencia que los artefactos mediadores diseñados para articular y sincronizar a las personas podrían reducir la fricción de las interacciones sociales. A diferencia de la teoría de juegos, su discusión no se enfoca en cómo las personas maximizan sus resultados individuales, sino en cómo las personas encajan actividades interdependientes que ocurren en un ámbito de trabajo común.

Los conceptos de cooperación y colaboración comparten las mismas raíces etimológicas: com ("con") y operare ("trabajar"), que también es el significado de laborare (Harper, 2001-2018). Ambas formas de interacción requieren una acción coordinada para reducir la viscosidad social (Salamanca, en prensa). Los actores sociales exhiben coordinación cuando satisfacen mutuamente sus expectativas de manera oportuna. De esta manera, logran maximizar la eficiencia de la interacción. Sin embargo, aunque los conceptos de cooperación y colaboración tienen características en común, nosotros las diferenciamos en base a tres aspectos derivados de observaciones a peatones que interactuaban en situaciones urbanas (ver Tabla 1). La direccionalidad de las metas entre partes que interactúan es consecuente cuando la realización de sus metas no interfiere con la realización de las metas de la otra parte. Por el contrario, esta direccionalidad es conflictiva cuando la realización de las metas de una de las partes impide la realización de las de la otra. La compatibilidad de los programas de acción de los actores está definida por la afinidad de sus métodos para alcanzar sus metas. Si estos comparten de forma armoniosa recursos como el tiempo o el lugar, sus programas

that optimizes instead the average outcome across all players. A different but complementary approach to coordination is shown by Schmidt and Simone's study of artifacts mediating cooperative work (1996). Schmidt and Simone conclude that artifacts and protocols facilitate the articulation of work and alleviate the need for ad hoc deliberation and negotiation. This is evidence that mediating artifacts designed to articulate and synchronize people could reduce the friction of social interaction. Unlike game theory, their discussion is not focused on how people maximize their individual outcomes, but rather on how people mesh interdependent activities that occur on a common field of work.

Cooperation and collaboration share the same etymological roots: com ('with') and operare ('to work'), which is also the meaning of laborare (Harper, 2001-2018). Both forms of interaction require coordinated action to reduce social viscosity (Salamanca, in press). Social actors exhibit coordination when they mutually fulfill each other's expectations in a timely way. By doing so, they maximize the interaction efficiency. Albeit cooperation and collaboration share significant commonalities, I differentiate them on the basis of three aspects derived from observations of unacquainted pedestrians interacting in urban settings (see Table 1). The directionality of goals of interacting parties is consequent when the achievement of one's 
de acción son congruentes (Latour, 2005); de lo contrario, sus programas son discordantes. Finalmente, la consideración de los intereses de los otros por parte de los actores es altruista si se preocupa por la realización de las metas de sus congéneres o egoísta si solo se preocupa por alcanzar sus propias metas.

Definimos "colaboración" como la interacción social coordinada en la cual dos o más actores o colectivos alinean sus programas de acción para alcanzar metas consecuentes, bajo el precepto de que mu-

Tabla 1. Resumen de los aspectos de la interacción social entre las partes

Aspectos de la interacción entre las partes

\begin{tabular}{llll} 
Interacción social & $\begin{array}{l}\text { Direccionalidad } \\
\text { de las metas }\end{array}$ & $\begin{array}{l}\text { Compatibilidad } \\
\text { de los programas } \\
\text { de acción }\end{array}$ & $\begin{array}{l}\text { Consideración } \\
\text { de los intereses } \\
\text { de los otros }\end{array}$ \\
\hline $\begin{array}{l}\text { Colaboración } \\
\text { Cooperación }\end{array}$ & Consecuente & $\begin{array}{l}\text { Congruente } \\
\text { Conflictivo }\end{array}$ & Altruista \\
\hline
\end{tabular}

Fuente: El autor.

tuamente presumen un interés altruista por contribuir con el otro. Por su parte, definimos la "cooperación" como la interacción social coordi" nada, pero en la cual las partes envueltas entretejen sus programas de acción discordantes de una manera egoísta, buscando el mejor resultado posible. Las partes dentro de una situación cooperativa tienen una interacción simbiótica, porque el éxito de uno no perjudica el del otro.

goals does not harm the achievement of other's goals. On the contrary, it is conflictive when the achievement of one's goals disrupts the achievement of others. The compatibility of the programs-of-action of actors is defined by the affinity of their goal-achievement methods. If their methods harmoniously share resources such as time or place, their programs-of-action (Latour, 2005) are congruent, otherwise they are discordant. Finally, the actors' consideration for others' interest is either altruistic if they care for each other's goal achievement, or selfish if they are only concerned with their own goal achievement.

Aspects of interaction between parties

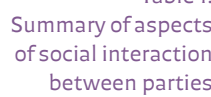

Table 1 Social interaction

Directionality Compatibility of Consideration for
between parties

\begin{tabular}{llll} 
& of goals & programs-of-action & others' interest \\
\hline Collaboration & Consequent & Congruent & Altruistic \\
Cooperation & Conflicting & Discordant & Selfish
\end{tabular}

Source: The author.

I define 'collaboration' as the coordinated social interaction in which two or more actors or collectives align their programs-of-action to achieve consequent goals, on the basis that they mutually presume an altruistic 
Al combinar estos tres aspectos de la interacción social se producen distintos tipos de resultados. Es más común observar colaboración entre actores cuando sus metas son consecuentes y sus métodos congruentes; mientras que se observa más cooperación cuando las metas de los actores están en conflicto y sus métodos son discordantes. La consideración de los intereses del otro es un aspecto psicológico que puede cambiar durante el transcurso de la interacción.

\section{FORMAS ELEMENTALES DE SOCIABILIDAD}

En la teoría de los modelos relacionales Fiske $(1992,2004)$ introduce un marco teórico que describe la manera en que las personas consideran las interacciones interpersonales, así como la manera en que estas operaciones delinean los principales estándares de la moral social. Este es un marco muy práctico para incorporar normas, motivos y principios morales en artefactos mediadores. En este apartado pretendemos ofrecer una mirada general a la propuesta de Fiske, específicamente en relación con las interacciones colaborativas y cooperativas.

Fiske asegura que las personas tienden naturalmente a buscar, hacer, sostener, reparar, ajustar, juzgar, construir y sancionar las relaciones sociales. Durante el proceso, todo el mundo utiliza el mismo conjunto de modelos relacionales, los cuales pueden resumirse en cuatro esquemas fundamentales. La investigación de Fiske, apoyada por evidencia de diferentes culturas alrededor del mundo, sostiene que, a pesar del dominio de la acción o cognición social, es posible distinguir

interest to contribute to one another. 'Cooperation' is also a coordinated social interaction, but the involved parties selfishly weave their discordant programs-of-action pursuing their best possible outcome. Parties in a cooperative situation have a symbiotic interaction because their successes do not hinder one another.

Different combinations of these three aspects produce different kinds of social results. It is more likely to observe collaboration between actors when their goals are consequent and their methods are congruent; whereas cooperation is observed when actors' goals conflict and their methods are discordant. The consideration of others' interest is a psychological aspect that may change over the course of the interaction.

\section{ELEMENTARY FORMS OF SOCIALITY}

Under the name Relational Models Theory, Fiske $(1992,2004)$ introduces a theoretical framework that describes how people regard interpersonal interactions, and how such operations shape the primary standards of social morality. This framework is extremely actionable when it comes to instantiate norms, motives and moral principles in mediating artifacts. In this section I intend to give a general account of Fiske's framework, specifically in relation to collaborative and cooperative interactions. 
las operaciones o relaciones sociales relevantes cuando las personas intercambian, contribuyen y distribuyen cosas; organizan el trabajo; y dotan a los artefactos, a la tierra, y al tiempo con significación social.

Los juicios morales de las personas y las posiciones ideológicas de los individuos en una sociedad están clasificados en estas cuatro estructuras: 1) Distribución comunal o del común (communal sharing), que es una forma de sociabilidad en la cual los miembros de un grupo se tratan a todos como iguales entre sí, enfocándose en aspectos en común e ignorando las identidades distintivas. Los lazos familiares suelen estar presentes y la actitud natural entre las personas es de altruismo y amabilidad. Los inmigrantes de un mismo país en una tierra extranjera y las comunidades religiosas son instancias de este tipo de sociabilidad. 2) Relaciones de rango de autoridad, que se basan en un modelo asimétrico entre personas que están ordenadas jerárquicamente. La posición de cada individuo en esta clasificación implica niveles de prestigio, prerrogativas y privilegios, los cuales siempre benefician a quienes están en lo más alto. Las estructuras militares y familiares están gobernadas por este modelo. 3) Las relaciones de igualdad de condiciones se basan en un modelo de equilibrio y de correspondencia de todos para uno y uno para todos. Por ejemplo, la moralidad subyacente dictaría que cuando se distribuye una serie de recursos, a cada persona le debería tocar una parte justa y que la dirección y magnitud de cualquier desbalance sería importante; los favores recíprocos, el compartir el vehículo y las represalias tipo

Fiske claims that people naturally tend to seek, make, sustain, repair, adjust, judge, construct, and sanction social relationships. In the process of doing so, everyone uses the same set of relational models, which can be clustered in four elementary schemata. Fiske's research, supported by evidence from different cultures around the world, contends that regardless of the domain of social action or cognition, it is possible to distinguish the relevant social operations or relations when people exchange, contribute, and distribute things; organize labor; and endow artifacts, land, and time with social significance.

Their moral judgments and ideological positions of individuals within a society fall within one of these four structures: 1) Communal sharing is a form of sociality in which the members of a group treat each other as equals, focusing on commonalities and disregarding distinctive identities. Kinship ties are usually present, and the natural attitude among them is altruism and kindness. Immigrants from the same country in a foreign land and religious communities are instances of this form of sociality. 2) Authority ranking relationships are based on a model of asymmetry among people who are hierarchically ordered. The position of each individual in the ranking entails levels of prestige, prerogatives, and privileges, always benefiting those who are at top of the ranking scale. Military and family structures are 
"ojo por ojo, diente por diente" son ejemplos de este modelo. 4) Las relaciones de precios de mercado se basan en un modelo de proporcionalidad en el cual todas las características cualitativas y cuantitativas relevantes de la relación se reducen a un solo valor o utilidad métrica que permite una comparación universal. La moralidad de este modelo se basa en cálculos racionales de eficiencia o utilidad. Está claro que el ejemplo arquetípico de este modelo es el mercado, donde el dinero es la métrica absoluta.

No se espera que estos cuatro modelos sean considerados como excluyentes. Fiske sostiene que las personas generalmente pertenecen simultáneamente a muchos grupos sociales gobernados por alguno de estos esquemas. La realidad de la vida social es una combinación de estos y cuando las personas se enlistan en instituciones o estructuras sociales interactúan bajo la lógica del modelo dominante o bajo una combinación de estos. Fiske describe los modelos como si cada uno fuese una forma de sociabilidad aislada solo para simplificar y aclarar los conceptos. Los casos residuales, es decir aquellos que no están caracterizados por ninguno de los esquemas mencionados anteriormente, son considerados como interacciones asociales o nulas. Las primeras son aquellas en las que las personas consideran a los demás como instrumentos para alcanzar un fin mayor. Las nulas son aquellas en las que las personas ignoran los objetivos de los otros, su presencia o sus concepciones.

Nosotros desarrollamos nuestro análisis enfocándonos en modelos

governed by such a model. 3) Equality matching relationships are based on a model of even balance and one-for-one correspondence. For example, the underlying morality would dictate that when distributing a pool of resources each person should be entitled to an equal share, and that the direction and magnitude of any imbalance would be meaningful. Reciprocal favors, car-pooling, and tit-for-tat retaliation are examples of this model. 4) Market pricing relationships are based on a model of proportionality in which all the relevant qualitative and quantitative features of the relationship are reduced to a single value or utility metric that allows universal comparison. The morality of this model is based on rational calculations of efficiency or utility. Of course, the archetypical example of this model is the market in which money is the absolute metric.

These four models are not intended to be regarded as mutually exclusive. Fiske contends that people typically belong simultaneously to several social groups that are governed by one of these four schemata. The reality of social life is a combination of them, and as people get enrolled in institutions or social structures, they interact under the logic of the dominant model or a nested combination of them. It is only for simplicity and clarity that Fiske describes them as if each one was an isolated type. The residual cases, not characterized by any of the above schemata, are either asocial 
de distribución "comunal" o de igualdad de condiciones, porque estos no están vinculados al orden social impuesto por las métricas de mercado o las instituciones jerárquicas. En la distribución comunal, cada miembro de un grupo social tiene derecho a (por lo menos) los mismos privilegios que los demás. Se espera que los miembros contribuyan tanto como puedan y cada persona está obligada a compartir con otros miembros que necesiten recursos o pidan ayuda. En este tipo de grupo social, las personas utilizan los artefactos materiales como propiedad común; como depósitos de cosas comunes que se pueden utilizar cuando sea necesario. Los grupos de distribución comunal están basados en un sentido de pertenencia que proviene de los lazos familiares o de atributos compartidos que conforman su identidad. Esto da lugar al altruismo, la solidaridad y la amabilidad entre los miembros del grupo. En estas formas de sociabilidad no existen jerarquías. Cada persona es considerada un homólogo y la expresión más relevante de identidad es el sentido de afiliación al grupo. Los commons - históricamente las praderas comunes, pero también cualquier fuente de recursos compartidos- son la manifestación más importante de este modelo relacional porque en ellos el sentido de propiedad está compartido entre los miembros del grupo, quienes sienten que pueden utilizar los recursos libremente. Los terrenos disponibles pueden ser utilizados por cualquiera y nadie está obligado a pagar o compensar a nadie por su uso. Los bienes comunes son símbolos que representan al grupo como un todo; la tierra se asocia con la identidad de una familia que la trabaja

interactions or null interactions. Asocial interactions are those in which people regard others as instruments to achieve some ulterior end. Null interactions are those in which people ignore each other's goals, presence or conceptions.

I developed my analysis focused on communal sharing and equality matching models because they are independent of the social orders imposed by the market metrics or hierarchical institutions. In communal sharing, every member of a social group is entitled to at least the same privileges as the others. Members are expected to contribute as much as they can, and each person is obligated to share with other members who need resources or ask for help. In this kind of social group, people treat material artifacts as held in common; as pools of communal things to be used as needed. Communal sharing groups are based on a sense of belonging that comes from kinship ties or from the shared attributes that build their identity. This elicits altruism, solidarity, and kindness among the members of the group. In such a form of sociality, there is no hierarchy within the group. Individuals are regarded as homologous and the most relevant expression of identity is one's expression of affiliation to the group. Commons - historically, communal grasslands, but also any shared pool of resources - are the most important manifestation of this relational model 
por generaciones o con la vivienda heredada de los ancestros.

Durante el proceso de toma de decisiones en los grupos de distribución comunal, se suele buscar el consenso y el juicio compartido. A pesar de que los individuos tengan posiciones personales, ellos consideran la decisión conjunta en términos del beneficio colectivo en lugar de hacerlo en función del beneficio individual. Esta lógica grupal genera una uniformidad de expresión entre los miembros debido a la tendencia de corresponder al grupo en referencia.

Un problema derivado de la lógica de distribución comunal es el problema de la sustentabilidad de sus recursos. Todas las personas dentro de un grupo con derecho a usar la misma fuente de recursos limitados debe usarlos responsablemente para evitar agotarlos. Este problema está ilustrado en The Tragedy of the Commons (Hardin, 1968). Más formalmente, para que un grupo que utiliza una fuente de recursos sea sostenible, debe mantener por lo menos una masa crítica de recursos necesarios para su regeneración. Si las personas sobreexplotan los recursos, se rompe el equilibrio y se pone en riesgo toda la sustentabilidad. Esto significa que el sistema tiene una capacidad de carga (Epstein \& Axtell, 1996) que define el número máximo de individuos que pueden ser soportados de manera sustentable por una fuente de recursos. Si aumenta la población más allá de ese equilibrio, solo quedan dos escenarios posibles: 1) que la población siga aumentando, encaminándose inevitablemente a su extinción debido al agotamiento de los recursos, a pesar de que los individuos reduzcan su consumo en

because the sense of property is shared among group members who feel that they can use it freely. Available plots can be used by anyone and no one is obligated to pay or compensate for their use. Communal things are symbols that represent the group as a whole - land becomes associated with the identity of a family who works it over generations, or with the house they inherit from their ancestors.

A decision-making process in communal sharing groups often seeks consensus and joint judgment. Even though individuals have personal positions, they consider the joint decision in terms of collective benefit rather than individual benefit. Such group rationale creates uniformity of expression among the members due to the tendency to correspond to the reference group.

An issue derived from communal sharing logic is the problem of the sustainability of communal resources. Everyone in a group, entitled to use the same limited pool of resources, must use them responsibly in order to avoid their depletion. The problem is depicted in The Tragedy of the Commons (Hardin, 1968). More formally, a group using a pool of resources is a sustainable system if it maintains at least a critical mass of resources needed for its regeneration. If individuals over-exploit the resources the equilibrium is broken, jeopardizing the whole sustainability. This means 
aras de restaurar el equilibrio del sistema; o 2) que el grupo acuerde detener la expansión de la población. Hardin (1968) sostiene que no existe una solución técnica al problema del primer escenario, y que el segundo escenario requiere, para solventarse, un cambio dramático en la actitud moral del grupo: un autocontrol poblacional estricto.

La igualdad de condiciones es el otro modelo relacional que abordamos en este estudio. Este modelo implica una forma de sociabilidad en la cual cada miembro de un grupo social tiene derecho a los mismos privilegios y obligaciones sin distinciones de identidad. Es uno de los modelos fundamentales subyacentes a muchos sistemas morales y de leyes en diferentes culturas. Su principio fundamental aboga por un intercambio igualitario entre las partes que esperan una reciprocidad balanceada en relación con sus acciones. Así como en una pareja una persona espera reciprocidad de la otra, en un grupo más grande la reciprocidad proviene de los otros miembros considerados como una unidad.

La acción recíproca en grupos con igualdad de condiciones está balanceada si la persona que inicia la acción es correspondida con una acción equivalente. Si un amigo invita a otro a cenar, el invitado debe corresponder a la invitación con una similar. En los grupos de igualdad de condiciones el valor de cada interacción no se mide en escalas o radios, sino contando cuántas veces la direccionalidad de las interacciones apunta hacia una $u$ otra parte involucrada. El equilibrio deseado es que no haya diferencias entre las partes. Por ejemplo, si A

that the system has a carrying capacity (Epstein \& Axtell, 1996) that defines the maximal number of individuals a pool of resources can support sustainably. If the population grows beyond that equilibrium there are only two possible scenarios: 1) The population keeps on growing, heading inevitably to its extinction due to the depletion of resources, even though individuals reduce their consumption of resources aiming to restore the system's equilibrium; 2) The group agrees to stop the expansion of the population. Hardin (1968) argues that there is no technical solution to the problem of scenario 1 , and that scenario 2 requires a dramatic change in the moral stance of the group to solve it: strict self-control of population.

Equality matching is the other relational model of interest in this research. It entails a form of sociality in which every member of a social group is entitled to the same privileges and obligations without distinctions of identity. It is one of the fundamental models underlying many moral and law systems across different cultures. Its core principle argues for egalitarian exchange between parties who expect balanced reciprocity to their actions. If in a dyad, one expects reciprocity from the other party. If in a larger group, the reciprocity comes from theother members regarded as a unit.

Reciprocal action in equality matching groups is balanced if it equals the one being reciprocated. If someone is invited for dinner at a friend's 
invita a su amigo B a cenar dos veces, entonces $\mathrm{B}$ le debe dos invitaciones a $\mathrm{A}$, equivalentes a las comidas ofrecidas por A. Habrá igualdad de condiciones entre ambos cuando A acepte la segunda invitación de B. Lo importante en este caso no es el valor monetario, sino el número de gestos sociales. Ariely (2008) sugiere que las interacciones sociales se rigen por normas sociales y de mercado, cuyas lógicas pueden entrar en conflicto. Por ejemplo, dar un regalo tiene un alto valor desde una perspectiva social, pero es irracional desde una perspectiva mercantil. Cuando las normas sociales son más fuertes que las de mercado, prevalecen los fenómenos como el altruismo y la solidaridad.

Las personas en grupos con igualdad de condiciones no se sienten inconformes cuando su aporte es igual o mayor que el promedio; sin embargo, consideran menos aceptable un aporte levemente inferior que el común. En un grupo de referencia, como en el juego del ultimátum (Thaler, 1988), uno espera ganar al menos lo mismo que los demás, pero nunca menos. A pesar de la tendencia a buscar un equilibrio en las relaciones de igualdad de condiciones, siempre hay casos en los que las relaciones quedan en desbalance y pueden llegar incluso a romperse si este desequilibrio no se logra corregir. Por ejemplo, las relaciones de igualdad de condiciones pueden terminar convirtiéndose en relaciones de rango de autoridad si los beneficiarios no devuelven los favores y, en su lugar, devuelven respeto, lealtad, sumisión o deferencia.

home, the guest should reciprocate the invitation with a similar invitation. In equality matching groups, the value of each interaction is assessed not in scales or ratios but simply by counting how many times the directionality of theinteraction pointed towards one or another party. The desired equilibrium is a zero difference between them. For instance, if $A$ invites his friend $B$ for dinner twice, then $B$ owes $A$ two dinner invitations equivalent to the meals offered by $A$. B equally matches $A$ at the moment $A$ accepts $B$ 's second invitation. What matters is not the monetary value but the number of social gestures. Ariely (2008) argues that social interactions have social and market norms and that these logics may conflict. As an example, giving a gift is highly appreciated from a social perspective, but it is irrational from a market perspective. Where social norms are stronger than market norms, phenomena like altruism and solidarity prevail.

People in equality matching groups do not feel emotional discomfort when their share is equal or greater than the average, but they think that a slightly-less-than-equal share is barely acceptable. In a reference group, as in the ultimatum game (Thaler, 1988), one expects to do as well as the other members but never less well than them. Despite the tendency of equality matching relations to seek an equilibrium, there are cases where they may remain imbalanced, and they may even break up if the imbal- 


\section{ARTEFACTOS DISEÑAdos PARA LA MEDIACIóN SIMÉTRICA}

La argumentación de Fiske resulta especialmente útil para caracterizar interacciones interpersonales a través de diferentes formas de sociabilidad porque se basa en principios que no son específicos de ninguna cultura y considera a los miembros de un grupo social como individuos cargados de valor, cuyas acciones sociales se ven fuertemente sesgadas por la sociabilidad dominante del grupo. Sin embargo, intentar extender las sociabilidades de Fiske a sociabilidades simétricas entre humanos y no humanos pareciera no tener sentido. Por ejemplo, pareciera ilógico argumentar que una máquina computacional tenga los mismos derechos sociales o privilegios que tiene un ser humano. Sin embargo, desde una perspectiva post-humanista es plausible, e incluso necesario, porque los robots sociables y los artefactos inteligentes participan en interacciones sociales con humanos $y$, por ende, merecen una consideración diferente (Warwick, 2017).

A pesar de que los artefactos pueden no tener los mismos privilegios y obligaciones, pueden ser diseñados para materializar normas sociales, motivos y principios morales.

Podemos llamar norma a algo que se ve como una limitación externa proveniente de la sociedad y podemos llamarlo motivo cuando se percibe como algo que emana de otro individuo. La misma fuerza direccional se denomina principio moral cuando se le considera una obligación universal (Fiske, 1992, p. 704).

ance is never repaired. For example, equality matching relationships may end up in authority ranking relationships if recipients don't repay their 'debts' in kind, and instead persistently pay back with respect, loyalty, deference, or submission.

\section{SCRIPTED ARTIFACTS FOR SYMMETRICAL MEDIATION}

Fiske's argumentation is especially useful to characterize interpersonal interactions across different forms of sociality because it relies on principles that are not specific to any one culture and regards members of a social group as value-laden individuals whose social actions are heavily biased by the group's dominant sociality. But an attempt to extend Fiske's socialities to symmetrical human-nonhuman socialities appears nonsensical. At least it seems illogical to argue for a computational machine entitled to the same social obligations or privileges as the ones to which humans are entitled. However, from a posthumanist perspective it is plausible-and necessary - because sociable robots and smart artifacts participate in social interactions with humans and thus deserve a different consideration (Warwick, 2017).

Even though artifacts may not be entitled to privileges and obligations, they can be designed to reify social norms, motives and moral principles. 
La distribución comunal y la igualdad de condiciones son principios morales cuando se les considera un principio de unión que sustituye a las motivaciones individuales. Son motivos cuando un participante toma deliberadamente más medidas que los demás para restaurar la estabilidad del grupo en casos de desbalance. Finalmente, son normas cuando los participantes exigen comportamientos justos.

Esta investigación aboga por los actores materiales de una sociedad que tienen un rol mediador en las interacciones humanas proporcionales. Consideramos a los artefactos como participantes activos en las interacciones sociales, por lo que hemos investigado sobre formas de participación performativa en las cuales estos ayuden a articular interacciones cooperativas y colaborativas. Para hacerlo, enmarcamos las interacciones humano-humano como entrelazamientos sociales que no ocurren en el vacío, sino que habitan un contexto diseñado y manufacturado. Muchos de los casos discutidos en la literatura de la teoría del actor-red hacen referencia a la capacidad de agencia de los no-humanos (Bueger \& Stockbruegger 2017) y acogemos la idea de experimentar con artefactos performativos que extiendan las diadas humano-humano a triadas mediadas humano-artefacto-humano, donde los artefactos se comportan como mediadores. ¿Qué deben mediar? La articulación de programas de acción de las partes involucradas. Como mencionamos anteriormente, en el caso de interacciones colaborativas, los programas de acción están alineados, mientras que, en el caso de las interacciones cooperativas, estos están entretejidos.

\footnotetext{
Something is called a norm when it is viewed as an external constraint coming from society, and it is called a motive when it is perceived as emanating from within the individual. The same directive force is called a moral principle when it is regarded as a universal obligation. (Fiske, 1992, p. 704)
}

Communal sharing and equality matching are moral principles when they are regarded as a binding principle which supersedes individual motivations. They are motives when, in the case of an interaction imbalance, a partaker deliberately takes actions to restore the stability of the group more than others. And finally, they are norms when partakers mutually demand matching behaviors.

This research argues for material components of a society that have a mediating role in how humans interact proportionally. I regard artifacts as active partakers in social interaction, therefore I investigate forms of performative participation in which they help to articulate cooperative and collaborative interactions. To do so, I frame human-to-human interaction as social entanglements that do not occur in the void, but instead dwell in a designed and manufactured context. Many of the cases discussed in ANT literature remark the agential capacity of nonhumans (Bueger \& Stockbruegger 2017), and I embrace that strand of thinking to experiment with 
Este estudio analiza específicamente dos de las formas elementales de sociabilidad de Fiske y visualiza artefactos adaptables como instancias tangibles de objetos de conocimientos (Knorr-Cetina, 1997). Tales instancias tangibles podrían mediar rápidamente la actividad para la que están destinados si percibieran su contexto social y si pudieran significar direcciones de interacción potenciales basándose en las "creencias" codificadas por sus diseñadores.

\section{SIGNIFICACIÓN DE LENGUAJES DE ACCIÓN}

Para comprobar las ideas mencionadas anteriormente, creamos instancias de artefactos mediadores de modelos de relaciones de distribución comunal y de igualdad de condiciones para observar la evolución de interacciones colaborativas y cooperativas. Nos interesaba especialmente comprender cómo tales artefactos adaptables pueden representar efectivamente los principios morales subyacentes del modelo de relaciones dominante en una red de actores. Estos dos modelos de relaciones fueron escogidos porque reflejan una posición democrática sobre las organizaciones humanas. Para la distribución comunal, observamos la interacción de transeúntes en un paso peatonal diseñado para esto. En el caso de la igualdad de condiciones, observamos cómo un tablero especial mediaba el surgimiento del altruismo entre jugadores que tenían que construir simultáneamente réplicas de un modelo de Lego.

Los artefactos fueron concebidos como agentes sociales según la

performative artifacts that extend the human-human dyads into mediated human-artifact-human triads where the artifacts behave as mediators. What do they mediate? The articulation of programs-of-actions of involved parties. As indicated earlier, in the case of collaborative interactions the programs-of-actions are aligned, whereas in the case of cooperative interactions they are weaved.

This research specifically takes two of Fiske's elementary forms of sociality and envisions adaptive artifacts as material instantiations of knowledge objects (Knorr-Cetina, 1997). Such material instantiations could promptly mediate the ongoing activity to which they are enrolled if they sense their social context and signify potential interaction directions based on their scripted 'beliefs'.

\section{SIGNIFYING ACTION-LANGUAGES}

In order to test the ideas discussed above, I staged instances of artifact mediators of communal sharing and equality matching relational models and observed the evolution of cooperative and collaborative interactions. I was particularly interested in understanding how such adaptive artifacts can effectively signify the underlying moral principles of the dominant relational model in a network of actors. These relational models were chosen 
abstracción del nivel de agencia de Dennett (1987). En la actitud física, su agencia fue definida en términos de acción-lenguaje utilizados para expresar las simetrías o desbalances en la interacción y advertir gráficamente a los individuos sobre posibles conflictos posteriores, así como choques de trayectoria o disminución desproporcionada de las piezas del rompecabezas. Las señales de advertencia tenían dos modos (Sennett, 2012; Tomasello, 2010): en el modo "subjuntivo" (por ejemplo "puedes hacer X cosa"), el tono de la señal es una sugerencia de la distribución ideal de los recursos proporcional al número de personas involucradas en la interacción. En el modo "prescriptivo" (por ejemplo, "debes hacer X cosa"), las señales son indicativas, mostrando también una distribución balanceada de los recursos, pero enfatizando una dirección de acción. En el caso del paso peatonal inteligente, el patrón estático del ancho de la calle fue reestructurado como un patrón dinámico natural que sugería trayectorias o puntos de conflictos anticipados de manera adaptable (Figura 1). En el caso del tablero inteligente, una proyección circular sobre la superficie de una mesa sugería a cada individuo qué tipo de pieza de Lego podría ser compartida y mostraba la distribución ideal de las piezas entre los individuos (Figura 2).

En la actitud de diseño, la agencia de los artefactos fue definida en términos de los programas de acción diseñados para fomentar interacciones colaborativas o cooperativas de manera adaptable. Un conjunto de sensores y actores permitió a los artefactos recabar información, procesarla según los guiones y adaptarla a la información mostrada en tiempo real.

because they reflect a democratic position about human organizations. For communal sharing, I observed the interaction of pedestrians on a custom designed smart crosswalk. As for equality matching, I observed how a smart tabletop mediated the emergence of altruism among players prompted to build replicas of Lego models concurrently.

The artifacts were conceived as social agents following Dennett's level of agency abstraction (1987). At the physical stance, their agency was defined in terms of the action-language used to convey the symmetries or unbalances of the interaction, and graphically warn the subjects about potential conflicts ahead, such as trajectory clashes or disproportional depletion of puzzle pieces. The warning signals had two modes (Sennett, 2012; Tomasello, 2010): In the 'subjunctive' mode (i.e. "you might do X"), the signaling tone is a suggestion of the ideal distribution of resources proportional to the number of people in interactions. In the 'prescriptive' mode (i.e. "you should do X"), the signaling tone is indicative, also displaying a balanced distribution of resources, but emphasizing an action direction. In the case of the smart crosswalk, the street-wide static pattern was recast as a dynamic stripped pattern that adaptively suggested trajectories or mark zones of anticipated conflicts (Figure 1). In the case of the smart tabletop, a pie-shaped projection on the screen suggested 
Figura 1: Sujetos caminando sobre un paso peatonal inteligente ensamblado en un contexto de laboratorio. Fotografía: El autor, 2011.

Figura 2: Izquierda: Dos instancias del rompecabezas referencial que debía ser replicado por los sujetos del experimento. Uno compuesto por 8 piezas grandes y el otro por 7 grandes y 2 pequeñas. Derecha: Tablero inteligente. Ilustración y fotografía: El autor, 2011.
Finalmente, en la actitud intencional, tanto transeúntes como jugadores estuvieron involucrados en tareas diseñadas para materializar los principios morales subyacentes a configuraciones sociales, tales como una acera o un tablero de juego de suma cero, y para apoyar a personas que actúan según el modelo relacional dominante de la comunidad.

Durante las observaciones evaluamos cuantitativa y cualitativamente la trayectoria de las negociaciones de los sujetos, la evolución de la interacción, el tiempo para completar su tarea y los grados de coordinación, así como el contenido y frecuencia de sus conversaciones. Las
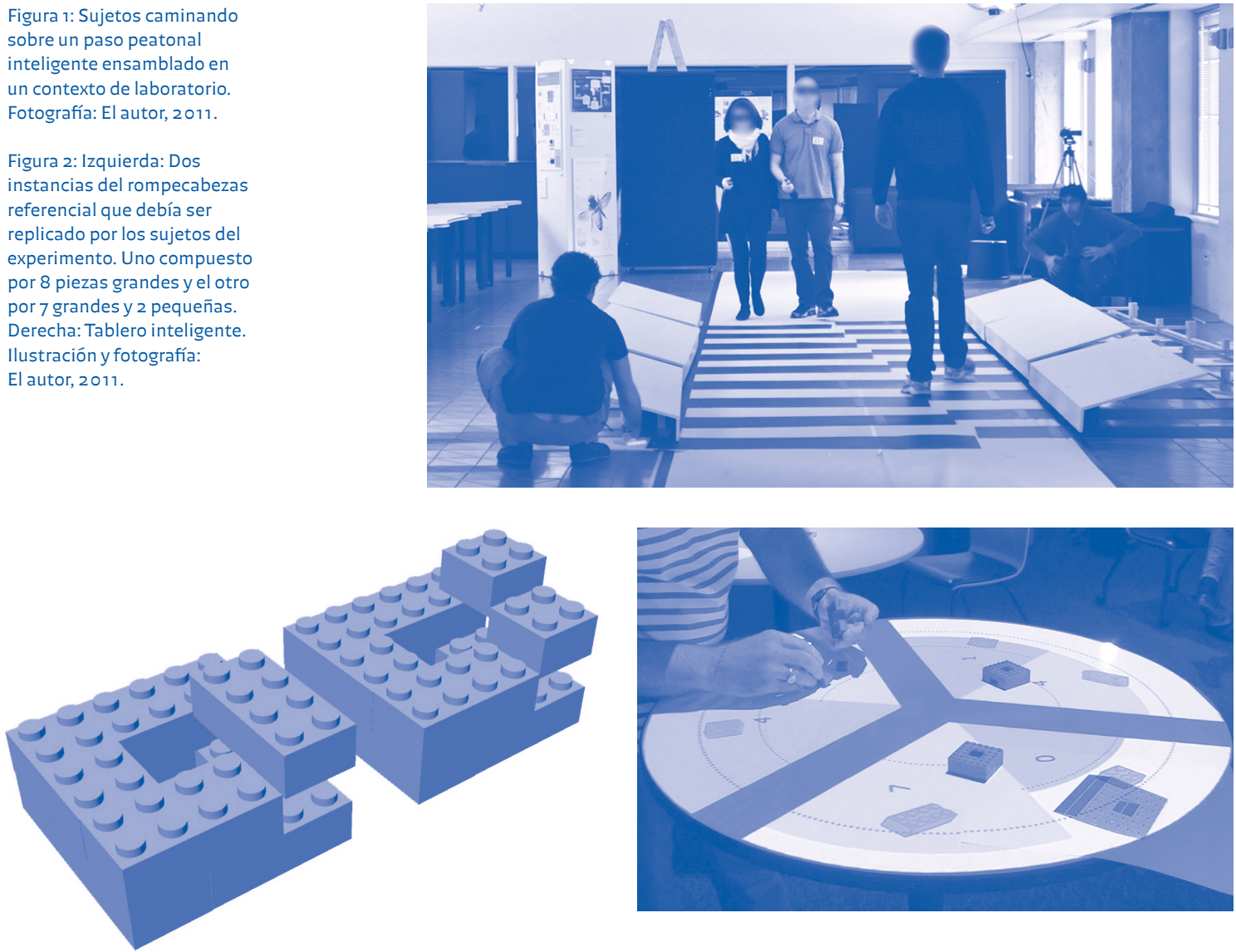

to each subject what kind of Lego piece could be shared, and displayed the ideal distribution pieces across subjects (Figure 2).

At the design stance, the agency of artifacts was defined in terms of the programs-of-action scripted to adaptively foster either cooperative or Figure 1: Subjects walking on a smart crosswalk deployed in a laboratory setting. Photograph: The author, 2011.

Figure 2: Left: Two instances of the reference puzzle to be replicated by subjects. One composed of 8 long blocks and the other of 7 long and 2 short blocks. Right: Smart tabletop. Illustration and photograph: The author, 2011. collaborative interaction. Sets of sensors and actuators enabled the artifact to collect data, process it following the scripts, and adapt the displayed information in real time.

Finally, at the intentional stance, both walkers and players were involved in tasks customized to reify the underlying moral principles of social settings such as the sidewalk or a zero-sum table game, and support individuals who play according to the community's dominant relational model.

During the tests, I assessed qualitatively and quantitatively the sub- 
conclusiones del estudio del paso peatonal inteligente están plasmadas en "Smart Artifacts Mediating Social Viscosity" (Salamanca, en prensa). En este ensayo describimos los hallazgos observados armando modelos de Lego en mesas con tableros inteligentes.

\section{EL DISEÑO DEL ESTUDIO Y SUS RESULTADOS}

Doce sujetos fueron asignados a tres mesas con tableros inteligentes, pero los grupos no fueron definidos como equipos. Todos los sujetos estaban autorizados para tomar una pieza por turno. Los sujetos eran responsables de armar su propio modelo, idéntico al de los demás. El objetivo era conseguir armar un rompecabezas sólido que fuese una réplica en forma y color del modelo original. Se explicaron oralmente las reglas de juego a los participantes y se hizo énfasis en que el juego no tenía puntaje y que no era una competencia. Se dejó claro que el objetivo no era terminar primero y que no habría premios para quienes lograran el objetivo. El juego no tenía restricción de tiempo y terminaba cuando todos los jugadores en la mesa terminaran sus rompecabezas. Al finalizar se llevó a cabo una ronda abierta de preguntas y respuestas sobre la actividad, la que se grabó en video.

La pila de piezas en cada mesa tenía la cantidad exacta necesaria para construir cuatro réplicas de un modelo referencial, una por sujeto, usando siete piezas grandes más dos pequeñas. En el momento en que un participante utilizaba más piezas de las esperadas, se rompía el balance de la pila y el tablero inteligente alertaba a los sujetos que

jects' trajectory negotiations, turn taking, time to task completion, degrees of coordination and the content and frequency of conversations. The conclusions of the smart crosswalk study are described in 'Smart Artifacts Mediating Social Viscosity' (Salamanca, in press). Herein, I describe the findings of observing building puzzles on tables with smart tabletops.

\section{STUDY DESIGN AND RESULTS}

Twelve subjects were assigned to three smart tables, but the groups were not defined as teams. Each subject was equally entitled to draw one block from the pool per turn. Subjects had their own accountable goal, identical to each other's, that is, to build the model. The criterion of success was to build a solid puzzle that replicates the shape and color of the original model. The game rules were explained verbally, and it was emphasized that the game had no scores and that it was not a competition. It was clearly stated that finishing first was not the aim of the game and that there were no prizes if they succeed. The game had no time restriction and ended when all the players at the table completed their puzzles. An open-ended round of questions and answers about the activity was conducted and video-recorded afterwards.

The pool of blocks in each table has the exact number of pieces to build 
existía un desbalance. Si se da alguna consideración altruista entre los jugadores y el mediador señala potenciales direcciones de acción, algún jugador puede deshacer su propio rompecabezas e intercambiar piezas con el sujeto que no será capaz de completar el suyo.

El tablero inteligente, diseñado para operar en tiempo real, muestra numéricamente y en proporciones de forma de cuña la secuencia y el número de piezas utilizadas, indicando cómo se distribuyen los recursos mientras se va desarrollando el juego, por lo que facilita el cálculo y el estudio de los desbalances del modelo hipotético de igualdad de condiciones del juego.

Las variables analizadas fueron la duración de la jugada de cada participante, la secuencia y número de piezas utilizadas por cada jugador y las sugerencias o negociaciones verbalizadas entre los jugadores. La duración de las jugadas representaba las dificultades de los jugadores durante su jugada. Esta variable no es lo suficientemente fuerte por sí sola, pero ofrece un indicio razonable de la exigencia cognitiva del jugador. La secuencia y el número de piezas indicaban cómo se distribuían los recursos durante la evolución del juego, por lo que facilitaban el procesamiento y estudio de los desbalances en el modelo hipotético de igualdad de condiciones propuesto en el juego. Finalmente, las sugerencias verbales eran signos evidentes de interacciones sociales.

Los resultados demostraron que no hubo cooperación en todas las mesas e incluso que, cuando ocurría, solo sucedía al final del juego, cuando los jugadores veían a sus contrapartes esforzándose por re-

four replicas combining seven long blocks plus two short blocks. The moment one participant uses more blocks than expected, the pool balance is broken, and the smart tabletop will alert subjects of the imbalance. If there is an altruistic consideration among players, and the mediator signifies potential action directions, then someone may undo her own puzzle and trade the bricks with the subject who won't be able to complete her puzzle.

The smart tabletop, operating in real time, displays numerically and in the proportions of wedge shapes the sequence and number of pieces used, indicating how resources are distributed as the game evolves and therefore facilitating the computation and study of imbalances of the hypothesized equality matching model of the game.

The variables observed were the duration of each player move, the sequence and number of pieces used by each player, and the verbalized suggestions or negotiations between players. The move duration was a proxy of player's struggle during a move. This variable is not robust enough by itself, however it provides a reasonable indicia of the player's cognitive demand. The sequence and number of pieces indicated how resources were distributed as the game evolved and therefore facilitated the computation and study of imbalances of the hypothesized equality matching model of the game. Finally, verbal suggestions were evident signs of social interaction. 
Figura 3: Evolución del juego de rompecabezas en una mesa inteligente. La cooperación solo tuvo lugar durante la ronda 6 , cuando los jugadores vieron a sus contrapartes luchando por resolver sus rompecabezas, ignorando las señales de desbalance que había mostrado la mesa inteligente con anterioridad. Arriba (Estado del rompecabezas) A, B, C, D, corresponden a cada uno de los cuatro jugadores. Las columnas con los bloques en negro indican la ronda en la que los jugadores completaron su rompecabezas. Centro (Duración del turno): Tiempo transcurrido para completar el rompecabezas. Abajo (Estado de la pila): Distribución de las piezas sobrantes. Ilustración: el autor, 2011.

Figure 3: Puzzle game evolution at a smart table. Cooperation only occurred at round 6 when players saw their counterparts struggling to solve their puzzles, ignoring the early imbalance signals displayed by the smart table. Above (Puzzle status): A, B, C, D correspond to each of the four players. The black blocks columns indicate the round in which players completed their puzzle. Middle (Turn duration): Elapsed time to complete the puzzle. Below (Pool status): distribution of remaining blocks. Illustration:

The author, 2011 solver sus rompecabezas (Figura 3). Los juegos duraron siete rondas, con un promedio total de duración de 6:35 minutos. Fue solo durante la última ronda que los jugadores empezaron a hablar acerca de cómo ayudar a los que corrían el riesgo de fallar en su tarea. En la parte superior de la Figura 3, el estatus del rompecabezas está representado como columnas que muestran el uso de piezas de los jugadores denominados A, B, C y D en una de las mesas inteligentes identificada con el número 3. Las columnas superiores representan las piezas grandes y las columnas inferiores las piezas pequeñas. La distribución de los recursos tuvo un progreso relativamente balanceado hasta la ronda 4. En la ronda 5, el jugador B finalizó su rompecabezas utilizando únicamente piezas grandes, impidiendo que otro lograra completar el suyo. Al llegar a ese punto, uno de los jugadores agotó las piezas grandes y exclamó: «hmmm, se nos acabaron las grandes». En la ronda 6, los jugadores A y D completaron sus rompecabezas con la distribución ideal (7 grandes y 2 pequeñas). En esa misma ronda, la jugadora $C$ necesitaba una grande, pero como se habían agotado, se vio forzada a tomar una pequeña, aumentando el desbalance de su rompecabezas. En la ronda 7, la duración del turno de la jugadora C aumentó dramáticamente (ver el apartado del medio en la figura 3). En su turno, todos los jugadores participaron y contribuyeron a encontrar una solución a su rompecabezas. El jugador D sugirió lo siguiente a $\mathrm{B}$ y $\mathrm{C}$ : «ipor qué no intercambian una grande por dos pequeñas?». El jugador A respaldó la sugerencia del jugador D y, tras

The results showed that cooperation did not occur in all tables, and even when it did, it occurred only at the very end of the game when players saw their counterparts struggling to solve their puzzles (Figure 3 ). The games lasted for seven rounds with an averaged total duration of 6:35 minutes. Only during the very last round players started to talk about how to help the ones at risk of failing the task. In the top section of Figure 3 , the puzzle status is represented as columns of squares showing the usage of blocks by players named $A, B, C$ and $D$ at smart table 3 . Top columns represent the long building blocks and bottom columns the short building blocks. The distribution of resources at smart table 3 had relatively balanced progress up until round 4 . In round 5 , player $B$ completed his puzzle using only long blocks, impeding someone from completing his/ her puzzle. At that point, one of the players realized the depletion of long blocks and exclaimed: "Hmmm, we are out of long ones." In round 6 , players $A$ and $D$ completed their puzzles with the ideal distribution of pieces ( 7 long +2 short). In the same turn, player $C$ needed one long block but because the pool ran out of them, she was forced to draw a short one increasing her puzzle imbalance. In round 7, turn duration of player $\mathrm{C}$ increased dramatically (See middle chart of Figure 3). In her turn, all the players took part and contributed to find a solution to her puzzle. 
Estado del rompecabezas • Puzzle status
$2 \begin{aligned} & \text { Jugadores } \\ & \text { Players }\end{aligned}$
Piezas grandes
Long blocks
Piezas pequeñas
Short blocks
1... Rompecabezas terminado
- Completed puzzle

Rondas Rounds

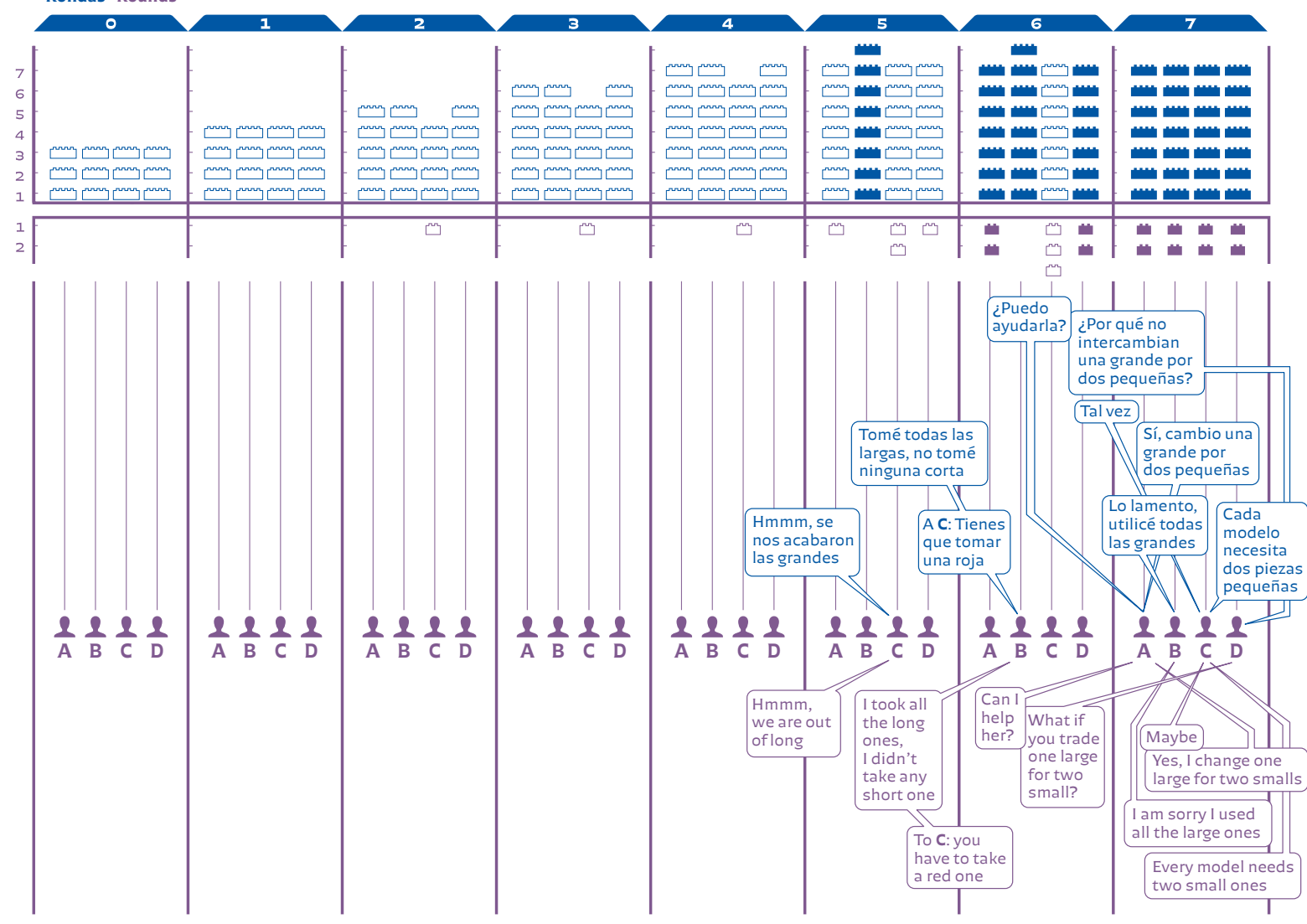

Duración de la jugada · Turn duration

$\frac{\ell}{c}$

120

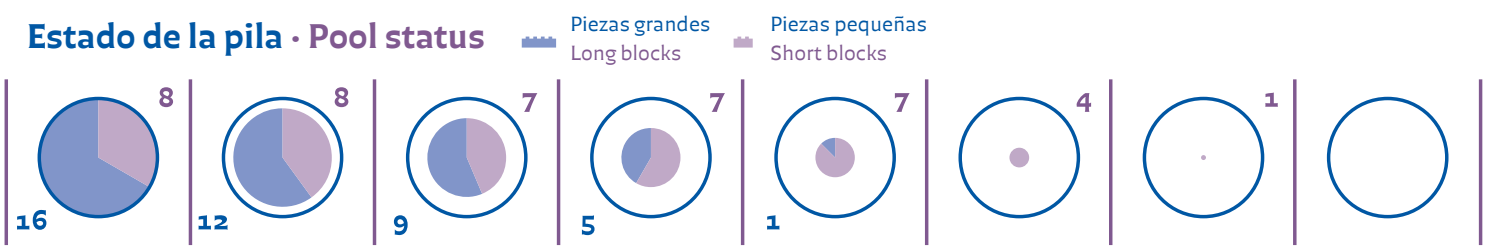


intercambiar sus piezas, el jugador B dijo, a manera de disculpas, «lo lamento, utilicé todas las grandes», y la jugadora $C$ confirmó que «cada modelo necesita dos piezas pequeñas».

En general, la cooperación se desencadenó por la escasez de recursos y el papel mediador del tablero inteligente no fue percibido. Espontáneamente surgió un mediador humano en una de las mesas, quien sugirió intercambios entre la jugadora que no había terminado el rompecabezas y los jugadores que sí lo habían hecho. Esto se debe, quizás, a que el mediador espontáneo había terminado su rompecabezas y su atención cognitiva ya no estaba enfocada en su meta. Aunque el tablero inteligente estaba señalando el mismo conflicto de desbalance que señaló el mediador humano, parece que este no tuvo un efecto significativo en los jugadores. Una explicación posible es que el tablero no hizo ninguna sugerencia de intercambio. En la entrevista posterior, los participantes afirmaron que ellos no entendían la información mostrada en la mesa y que casi no le prestaban atención a los dígitos mostrados sobre su superficie.

\section{DIScusión}

Ofrecemos cuatro proposiciones de diseño fundamentales que sirven como consideraciones para exploraciones futuras en el diseño de artefactos mediadores.

Player $D$ suggested to $B$ and $C$ : “Why don't you trade one large for two smalls?" Player A seconded player's D suggestion and after they traded their blocks, player $B$ apologetically said: "I am sorry, I used all the long ones", and player C confirmed: "Every model needs two small ones."

Overall, cooperation was triggered by resource scarcity and the mediating role of the smart tabletop was unnoticed. A human mediator spontaneously emerged in some of the tables, suggesting trade operations between the player with the unsolved puzzle and other players. This is perhaps due to the fact that the spontaneous mediator had completed her puzzle, and her cognitive attention was no longer focused on her goal. Although the smart tabletop was signaling the same conflicting imbalance pointed out by the human mediator, it appears that it did not have a major effect on the players. A possible explanation is that the tabletop was not making any trading suggestions. In the post-session interview, participants said that they did not understand the information presented by the table, and that they barely paid attention to the digits displayed on its surface.

\section{DISCUSSION}

I offer four fundamental design propositions that serve as considerations for future explorations in the design of mediating artifacts. 


\section{PROPOSICIÓN A}

Un artefacto es un mediador social relevante cuando constituye el foco de la actividad de la interacción de los actores humanos.

Siguiendo la definición de mediador de la teoría del actor-red, el mediador social relevante es un actor que canaliza y transforma las interacciones sociales. En contraste con un intermediario, el mediador no puede definirse por sus entradas y salidas. El foco de una actividad está definido como el punto donde se encuentran la acción y atención de los actores. La interacción social está distribuida entre todos los actores de la red, pero el epicentro de la acción no siempre coincide con el mismo foco. Nuestros estudios empíricos muestran que el enfoque de la actividad cambia de actor a actor, habilitando su potencial de mediación. Entre los actores no-humanos, solo aquellos que son foco recurrente de la actividad tienen el potencial de ser mediadores sociales efectivos. Si los artefactos inteligentes están destinados a mediar en las interacciones sociales, estos deben constituir un foco de la actividad para las partes que interactúan.

Se debe mostrar la información relacionada con la mediación en el foco de la actividad. Además, se puede notar que la información adicional ubicada en cualquier otra parte parece no ser útil para mediar los programas de acción de las personas. En el caso del estudio de los juegos de mesa, a pesar de que la mesa inteligente era un actor en la actividad, no fue el epicentro de la acción. Por el contrario, el foco de la actividad eran las piezas, los rompecabezas y la pila de piezas.

\section{PROPOSITION A}

An artifact is a relevant social mediator when it constitutes the focus of activity of human actors' interaction

Following the definition of mediator in Actor-Network Theory, the relevant social mediator is an actor that channels and transforms social interaction. In contrast to an intermediary, a mediator cannot be defined by its inputs and its outputs. The focus of an activity is defined as the point where actors' action and attention converge. Social interaction is distributed among all of the actors in the network, but the epicenter of action does not always coincide at the same focus. The empirical research studies show that the focus of activity jumps from actor to actor, enabling their potential for mediation. Among nonhuman actors, only those that are recurrent foci of activity have the potential to be effective social mediators. If smart artifacts are intended to mediate social interaction, they must constitute the focus of activity for the interacting parties.

Information related to mediation must be displayed at the foci of activity. Additional information placed somewhere else appears not to be useful in mediating people's programs-of-action. In the case of the table game studies, although the smart table was an actor in the activity, 
Cuando la coordinación se rige por las jugadas de cada turno, seguir el foco de la actividad resulta relativamente fácil para el investigador, porque la actividad del actor en turno se encuentra en el epicentro de la acción. El foco de la actividad para la red es lo que el actor hace y hacia donde dirige su acción.

\section{PROPOSICIÓN B}

Las acciones conectadas de los actores humanos y no-humanos muestran una viscosidad social que perjudica el flujo de acción.

Las interacciones sociales tienen un efecto de doble filo en un actor-red. Aun cuando estas ejercen atracción entre los actores, también ofrecen resistencia a la ejecución de sus programas de acción. Este efecto de doble filo en la interacción social representa la viscosidad social de la red. Esta viscosidad se define como la resistencia natural de un actor-red a la fluidez de las acciones de sus actores y está ocasionada por los impedimentos mutuos surgidos cuando los actores intentan ejecutar sus programas de acción. La viscosidad social tiene una correlación directa con el tamaño y la densidad de la red. Mientras que los colectivos más pequeños se coordinaron con mayor facilidad en los estudios, los colectivos más grandes tuvieron más dificultad para mantener interacciones coordinadas y balanceadas. Se pudieron evidenciar los efectos de la viscosidad social cuando los actores se desviaron de sus trayectorias, fracasando en alcanzar sus metas o cambiando su ritmo de acción. La viscosidad social responde a observaciones de

it was not at the epicenter of action. Instead, the focus of activity was located at the blocks, the puzzles and the pool of blocks.

When coordination is governed by turn-taking, tracking the focus of activity is relatively easy for a researcher because the activity of the actor in turn is at the epicenter of action. The focus of activity for the network is what the actor does and toward whom she is acting.

\section{PROPOSITION B}

The networked actions of human and nonhuman actors exhibit social viscosity that hinders the action flow.

Social interactions have a double-edged effect in an actor-network. While they pull actors together, they also offer resistance to the execution of the actors' programs-of-action. Such double-edged effects of social interaction represent the social viscosity of the network. Social viscosity is defined as the natural resistance of an actor-network to the fluidity of its actors' actions caused by the mutual disturbances elicited while they enact their programs-of-action. Social viscosity has a direct correlation to the size and density of the network. While smaller collectives coordinated easily in the studies, larger collectives struggled to maintain coordinated and balanced interactions. Evidence of the effects of social viscosity were 
comportamientos de las personas que parecen poco estructurados para un observador racional. Estas observaciones son desviaciones ocasionadas por lazos morales o emocionales entre los actores humanos, como el altruismo, lazos familiares o distancias jerárquicas entre los actores. En el campo de la economía del comportamiento, estos comportamientos poco estructurados se denominan "emocionales" o "irracionales" (Ariely, 2008).

\section{PROPOSICIÓN C}

Los participantes de una actividad tienen mayor posibilidad de reducir la viscosidad social si designan los recursos para ser utilizados de una manera en que no excedan un umbral de desbalance disperso.

Se pudo observar la menor fricción entre los sujetos cuando los jugadores adoptaron una estrategia en la cual ellos "imitaban" las jugadas de los otros. Esto es evidencia de una interacción colaborativa, porque hubo una alineación clara de sus metas y en la compatibilidad de sus acciones. Por el contrario, hubo señales de que los comportamientos cooperativos emergen cuando hay altos niveles de desbalance entre los rompecabezas. Un mediador inteligente debe estar atento a estos desbalances de recursos y dar señas cuando se excede un umbral definido.

Los mediadores inteligentes diseñados para promover acciones coordinadas entre los actores humanos pueden intensificar su modo de representar desbalances de recursos, desde resaltar conflictos potenciales (subjuntivo) hasta sugerir trayectorias (prescriptivo) una vez

observed when actors deviated from their trajectories, failing to achieve their goal or change the pace of action.

Social viscosity accounts for some observations of people's behavior that appear unstructured to a rational observer. Such observations are deviations caused by emotional or moral bonds between human actors such as altruism, kinship or hierarchical distances between actors. In the field of behavioral economics, such unstructured behaviors are named as 'emotional' or 'irrational' (Ariely, 2008)

\section{PROPOSITION C}

Participants in an activity have a higher chance to reduce social viscosity if they allocate the resources to be used so as not to exceed an imbalanced dispersion threshold.

The thinnest friction between subjects was observed when players adopted a strategy in which they mirrored others' moves. That is evidence of a collaborative interaction because there was a clear alignment of their goals, and of the compatibility of their doings. On the contrary, there were signs that cooperative behaviors emerge when there are high levels of imbalance among puzzles. A smart mediator must be aware of the imbalance of resources and signal when a defined threshold is exceeded. 
que el desbalance excede el umbral de dispersión. Este supuesto requiere mayor experimentación a futuro en condiciones de laboratorio.

\section{PROPOSICIÓN D}

Un artefacto mediador inteligente debería complementar el horizonte cognitivo de las personas con información acerca de lo que está fuera de su percepción o con aquello que no pueden predecir, en lugar de sobrescribir su entendimiento no-mediado del mundo.

Las personas que participan en una interacción social evitan la mediación efectiva cuando creen que tienen información suficiente para alcanzar sus metas, pero en muchos casos, los actores que ignoran la mediación de terceras partes al coordinar sus programas de acción pagan un alto precio, en comparación con aquellos que trabajan las situaciones conflictivas con la ayuda de mediadores inteligentes que extienden su percepción y horizonte cognitivo. Esto se pudo observar cuando los jugadores ignoraron las señas de la mesa inteligente y terminaron dedicando mucho más tiempo al final de las rondas para poder corregir los desbalances de sus rompecabezas.

Una explicación posible es que, en las interacciones cara a cara, los mediadores artificiales no son efectivos, porque su sentido de agencia es más débil que la agencia humana; en otras palabras, no son interpretados como actores en el contexto de la acción, porque sus actitudes físicas, intencionales y de diseño no representan las de un agente legítimo. El valor actual de los mediadores en la interacción social se

Smart mediators designed to promote coordinated actions between human actors can escalate their mode of signifying imbalances of resources from highlighting potential conflicts (subjunctive) to suggesting trajectories (prescriptive) once the imbalance exceeds the dispersion threshold. This assumption requires future experimentation under laboratory conditions.

\section{PROPOSITION D}

A mediating smart artifact should complement the cognitive landscape of people with information about what is outside of their perception or unforeseen by them, rather than overwriting their unmediated understanding of the world.

People enrolled in social interaction avoid effective mediation when they believe that they have enough information to fulfill their goals. But in many cases, actors that ignore third party mediation pay a higher cost in coordinating their programs-of-action, compared to those who get around conflicting situations with the help of smart mediators that extend their perception and cognitive landscape. This was observed when players ignored smart table signals and ended up spending longer times at the final rounds fixing their puzzle imbalances.

A possible explanation is that in face to face interactions artificial 
revela cuando completan la información que las personas necesitan acerca de hechos o tendencias, y no solo señalan, sino que actúan un mensaje correcto. Los mediadores artificiales podrían ser más efectivos si personificaran el lugar donde ocurre la interacción y recrearan los mensajes de mediación.

Es mucho más probable que los artefactos mediadores sean más efectivos en interacciones remotas o asíncronas que ubicados entre dos actores físicamente cercanos (Johansen, 1988), porque los actores cuentan con información más completa sobre los otros cuando estos actúan en el mismo espacio-tiempo. Por el contrario, los actores conectados que actúan en diferentes espacios o tiempos tienen información limitada de cada uno. Esto sugiere que es necesario explorar más los lenguajes de diseño performativo para la mediación.

\section{CONCLUSIÓN}

Hemos introducido una definición funcional de las acciones sociales cooperativas y colaborativas, caracterizadas por observaciones empíricas de interacciones no planificadas. La cooperación es definida como el desenmarañamiento de dos partes involucradas en una interacción discordante que intentan alcanzar metas en conflicto. La colaboración es la articulación de las partes en interacciones congruentes buscando alcanzar metas consecuentes. Las interacciones cooperativas entre actores humanos se benefician de mediadores inteligentes que resaltan conflictos potenciales. Por el contrario, las interacciones colaborativas

mediators are not effective because their sense of agency is weaker than human agency. In other words, they are not interpreted as actors in the action context because their physical, design and intentional stances do not put forward a legitimate agent. The actual value of mediators of social interaction is revealed when they complete the information people need about facts or trends, and not only signal but perform the right message. Artificial mediators could be more effective if they embody the locus of interaction and enact the mediation message.

It is highly likely that mediating artifacts are more effective in remote or asynchronous interactions than in co-located interactions (Johansen, 1988) because networked actors have more complete information of other actors when they act in the same space at the same time. Conversely, networked actors acting in different space or time have limited information of each other. This suggests that it is necessary to explore further performative design languages for mediation.

\section{CONCLUSION}

I have introduced a working definition of cooperative and collaborative social actions characterized by empirical observations of unplanned interactions. Cooperation is the satisfying disentanglement of two parties in 
se benefician de los mediadores inteligentes que sugieren soluciones para sortear conflictos previstos. Por lo tanto, los lenguajes de significación utilizados en la mediación de interacciones regidas por modelos relacionales de igualdad de condiciones o distribución comunal pueden tener mejores resultados si sus tonos de comunicación son subjuntivos (por ejemplo "puedes hacer X cosa") o prescriptivos (por ejemplo "deberías hacer $\mathrm{X}$ cosa”) respectivamente.

La coordinación de las interacciones colaborativas y cooperativas se ve afectada positivamente por cualquier mediador, pero al mismo tiempo, cada mediación puede retrasar la fluidez de la acción social. El desafío para los diseñadores de artefactos inteligentes es diseñar mediadores sociales que no impidan la fluidez de la acción social. Los objetivos grupales que requieren una distribución balanceada de los recursos pueden ser alcanzados con poca viscosidad social si los participantes no solo actúan de manera coordinada, sino que también mantienen una distribución balanceada de los recursos durante el proceso. D

discordant interaction trying to achieve conflicting goals. Collaboration is the articulation of parties in congruent interactions trying to achieve consequent goals. Cooperative interactions of human actors benefit from smart mediators that highlight potential conflicts. Conversely, collaborative interactions of human actors benefit from smart mediators that suggest solutions to circumvent a forecasted conflict. Therefore, signifying languages used in the mediation of interactions governed by equality matching or communal sharing relational models may have better results if their communication tones are subjunctive (i.e. "you might do X") or prescriptive (i.e. "you should do X"), respectively.

The coordination of collaborative and cooperative interactions is positively affected by any mediator, but at the same time, every mediation can delay the fluidity of social action. The challenge for smart artifact designers is to design social mediators that do not hinder the fluidity of social action. Collective goals that require a balanced distribution of resources can be achieved with low social viscosity if participants not only act coordinately but also maintain a balanced allocation of resources throughout the process. 


\section{REFERENCIAS / REFERENCES}

ARIELY, D. (2008). Predictably Irrational: The Hidden Forces that Shape our Decisions. New York, NV: Harper.

AXELROD, R. M. (1984). The Evolution of Cooperation. New York, nY: Basic Books.

BICKMORE, T. W., \& PICARD, R. W. (2005). Establishing and Maintaining Long-term Humancomputer Relationships. ACM Transactions on Computer-Human Interaction, 12 (2), 293-327. Doi: $10.1145 / 1067860.1067867$

BREAZEAL, C. L. (2002). Designing Sociable Robots. Cambridge, MA: MIT Press.

BULLINGTON, J. (2009). Agents and Social Interaction: Insights from Social Psychology. In c. Trajkovski \& S. c. Collins (Eds.), Handbook of Research on Agentbased Societies: Social and Cultural Interactions (pp. 35-80). Hershey, PA: Information Science Reference.

BUeGer, C., \& StockbruegGer, J. (2017). Actor-

Network Theory: Objects and Actants, Networks and Narratives. In D. McCarthy (Ed.), Technology and World Politics: An Introduction (pp. 42-59). London, England: Routledge.

CALLON, M., \& LAW, J. (1995). Agency and the Hybrid Collectif. South Atlantic Cuarterly, 94(2), 481-507.

CASSELL, J., \& BICKMORE, T. (2003). Negotiated Collusion: Modeling Social Language and its Relationship Effects in Intelligent Agents. User Modeling and User-Adapted Interaction, 13 (1-2), 89132 .

D'INVERNO, M., \& LUCK, M. (2001). Understanding Agent Systems. Berlin, Germany: Springer.

DENNETT, D. C. (1987). The Intentional Stance. Cambridge, MA: MIT Press.

EPSTEIN, J. M., \& AXTELL, R. (1996). Growing Artificial Societies: Social Science from the Bottom Up. Washington, DC: Brookings Institution.

FEHR, E., \& GÄCHTER, S. (2002). Altruistic Punishment in Humans. Nature, 415, 137-140.

FISKE, A. P. (1992). The Four Elementary Forms of Sociality: Framework for a Unified Theory of Social Relations. Psychological Review, 99(4), 689-723. Doi: $10.1037 / 0033-295 \times .99 .4 .689$

FISKE, A. P. (2004). Relational Models Theory 2.0. In N. Haslam (Ed.), Relational Models Theory: A Contemporary Review (pp. 3-24). Mahwah, NJ: Erlbaum.

HARDIN, G. (1968). The Tragedy of the Commons. Science, 162 (3859), 1243-1248. Doi: $10.1126 /$ science.162.3859.1243

HARPER, D. (Ed.) (2001-2018) Online Etymology Dictionary. Retrieved from: www.etymonline.com JOHANSEN, R. (1988). Groupware: Computer Support for Business Teams. New York, NY: Free Press.
KNORR-CETINA, K. (1997). Sociality with Objects.

Theory, Culture \& Society, 14(4), 1-30. Doi:

$10.1177 / 026327697014004001$

LATOUR, B. (1999). Pandora's Hope: Essays on the Reality of Science Studies. Cambridge, M A: Harvard University Press.

LATOUR, в. (2005). Reassembling the Social: An Introduction to Actor-Network-Theory. Oxford, England: Oxford University Press.

LAW, J. (1992). Notes on the Theory of the Actor Network: Ordering, Strategy and Heterogeneity. Systems Practice, 5(4), 379-393.

NICHOLSON, v. (2004). Cooperation and Coercion as Methods of Social Change. Wallingford, PA: Pendle Hill.

PARK, R. E., \& BURGESS, E. W. (1966). Introduction to the Science of Sociology ( $3^{\text {rd }}$ ed.). Chicago, IL: University of Chicago Press.

PICARD, R. W. (1995). Affective Computing. Cambridge, MA: Perceptual Computing Section, Media Laboratory, Massachusetts Institute of Technology.

SALAMANCA, J. (in press). Smart Artifacts Mediating Social Viscosity. In J. Vertesi \& D. Ribes (Eds.), Digitalsts: A Handbook and Fieldguide. Princeton, NJ: Princeton University Press.

SCHMIDT, K., \& SIMONE, C. (1996). Coordination Mechanisms: Towards a Conceptual Foundation of cscw Systems Design. Computer Supported Cooperative Work (csCW), 5(2-3), 155-200.

SEN NeTT, R. (2012). Together: The Rituals, Pleasures, and Politics of Cooperation. New Haven, ст: Yale University Press.

SIMMEL, G., \& LEVINE, D. N. (1971). On Individuality and Social Forms: Selected Writings. Chicago, I L: University of Chicago Press.

THALER, R. H. (1988). Anomalies. Journal of Economic Perspectives, 2(4), 195-206.

TOMASELLO, M. (2010). ¿Por qué cooperamos? Buenos Aires, Argentina: Katz Editores.

VON NEUMANN, J., \& MORGENSTERN, O. (1953). Theory of Games and Economic Behavior ( $3^{\text {rd }}$ ed.). Princeton, NJ: Princeton University Press.

WARWICK, K. (2017). A Practical Guide to Posthumans. Journal of Posthuman Studies, 1(1), 61-74. Doi: 10.5325/jpoststud.1.1.0061

WINNER, L. (1980). Do Artifacts Have Politics? Daedalus, $109(1), 121-136$. 